\title{
RESEARCH PAPER \\ MANIPULATING INDANTHRENE DYE AS A COLOURANT FOR SCREEN PRINTING ON INDIGENOUS VEG-TANNED LEATHER IN GHANA
}

\author{
J. O. B. Boahin, K. Asubonteng and V. E. Adu-Gyamfi \\ Department of Integrated Rural Art and Industry, Faculty of Art, \\ College of Art and Social Sciences, KNUST, Kumasi \\ Corresponding author: jboahin@gmail.com
}

\begin{abstract}
The Ghanaian indigenous leather industry serves as a source of employment for several people. However, lack of varied colour range for leather artifacts hinders the ability of the craftsmen to enhance the aesthetic value of leather artifacts to satisfy various tastes of customers. The research hinges on the conversion of indanthrene-dye into paste for making screen printing on leather. With cassava starch as a vehicle, the indanthrene-dyes were manipulated in three experiments and printed on vegetable tanned leather. The starch mixed well with the dyes into thick paste which made it possible to print on the grain surface of leather. Although indanthrene -dye has been known for dyeing fabric, the research has made it applicable for printing on leather. Leatherworkers are therefore presented with another technique of rendering a wide range of colours on leather. This will hopefully boost the economic relevance of the leather industry both at the local and international markets.
\end{abstract}

Keywords: Indanthrene-dye, cassava starch, vehicle, screen-printing, veg-tanned leather

\section{INTRODUCTION}

Ghanaian indigenous vegetable tanned leather has been produced by local tanners as the major raw material for use in a variety of leather products. However the choice and accessibility of colours suitable for application on leather is limited to red, brown, black and white. Moreover, most of the colourants used to dye the leathers are vegetable based and they fade off easily, particularly when exposed to sunlight. The situation has become a disincentive in the promotion of increased patronage and use of locally made leather and leather artifacts on both the local and international markets. The need to increase colour variety in order to accelerate and improve the socio-economic value of locally tanned leather and leather products has become critical. The objective of this re- 
search is to experiment on the possibility of manipulating indanthrene dye (vat dye) to make it applicable as a printing colourant (a colouring dye) for creating patterns on Ghanaian indigenous vegetable tanned leather in order to expand its material value and aesthetic quality.

\section{Review of related literature}

Indanthrene-dye is commonly known but seldom used for dyeing cellulose fibres. In Ghana, it is popularly used in dyeing fabric (as in tiedye and batik), and can be obtained in a variety of colours. Also, it has the advantage of easy penetration in fabric as compared to other available colourants on the market (Sackey, 2000). Dyes are well known to dissolve in their vectors (the liquid) because of the inherent composition of molecules. Sackey (2000) has also mentioned that dye-made prints present the brightest colours. Boahin (2008) and Asante (1980) have asserted that vat dye is commonly used by small-scale tie-dye and batik fabric industries, as well as large-scale textile industries, for dyeing cotton fabric in Ghana. Indanthrene-dyes include vat dyes mostly complex chemically, and insoluble in water. They therefore require manipulation with dye auxochromes to dissolve for use in fabric colouring (Asante, 1980). They must first be reduced to the leuco form in an alkaline solution of sodium hydrosulfite before application to the cotton or rayon fiber. Air oxidation fixes the dye strongly on the fiber, resulting in excellent wash-fastness and light-fastness (Baptista, 2009). According to Nguyan (2008), dyes or dyestuffs are soluble compounds that can either be absorbed and retained by the fiber or chemically combined with it. The colouring matter normally becomes an integral part of the fiber. Dyes are generally fast, that is, they retain their colours in the fiber throughout the textilemaking process, and under exposure to normal wear, including sunlight, water and detergent washing (Alen, 1971).

Nguyen (2008) and Lewin (2008) argue that vat dyes are not used on protein fibers because of the strong alkaline nature of their leuco-com- pound solutions. However, they are best used on cellulose fibers, especially where fastness to frequent and hard washing is required. Sharphouse (1995) has also emphasized that vat dyes were very difficult to use on leather owing to the alkalinity of the vat liquor affecting the tannages. However Boahin et al. (2011), have indicated that it can equally be applicable to leather, especially, where penetration of dyes into fibers needs to be achieved. They further maintain that with proper manipulation of the appropriate auxochromes, the dyestuff's suitability as a colourant for leather (which consist of fibrous protein called 'collagen') can be realized.

According to Lewin (2008) dyes are not to be confused with pigments, which are pulverized coloured substances that must be mixed with adhesive binding agents before being applied to surfaces. He explains further that since pigments do not dissolve fully in liquid but have to be applied in solutions as fine solid particles, they are prepared with chemical radicals which have the property of anchoring the desired dye effectively. Efficiently, conversion of dyes for printing would require the use of concentrated liquid substance as a vehicle before being applied to leather surfaces; and this could be starch, gelatin, or synthetic polymers. In this study, the choice of cassava starch as a vehicle is influenced by the fact that it is easily available, accessible and can be manipulated with water to achieve varied viscosities for the printing process.

Starch is a white, granular or powdery odourless, tasteless complex carbohydrate $\left(\mathrm{C}_{6} \mathrm{H}_{10} \mathrm{O}_{5}\right)$ $\mathrm{x}$, abundant in the seeds of cereal plants and in bulbs and tubers. Some common ones are mainly cassava, corn, wheat, rice and potato. The cost advantage and easy availability of cassava starch over other identified ones made it necessary to be selected for the research. Starch is almost insoluble in cold water and in alcohol, but with boiling water it gives a colloidal suspension that may form a jelly on cooling. Hot water changes starch slowly into 
smaller molecules called dextrins. Dextrin is any of the various polysaccharides obtained by hydrolysis of starch; a tasteless and odourless gummy substance that is used as a thickening agent and in dietary supplements.

The choice of screen printing technique comes as innovation towards application of colourants on leather. This is due to the fact that within the local environment screen printing is largely known to be used for textile printing. It is originally called silk-screen printing because of its silk-based stencils. Screen printing has become important in the production of a wide array of manufactured items, including decorative panels, printed circuit boards, touch-sensitive switches, plastic containers and printed garments. Cost (2008) has explained that, 'stencils' for commercial screen printing are usually produced by photomechanical means. The production process requires stretching a fine synthetic fabric or metal mesh over a rectangular frame, and then applying a photopolymer coating to the entire surface. Exposure of the photopolymer through a film positive causes it to harden in the areas not intended to print. The unexposed material is then washed away to create the open areas of the stencil. In the printing press, this screen is pressed against the surface to be printed, and ink is forced through the open areas of the stencil with a rubber 'squeegee'. Presses for screen printing range from simple manual devices for the small -scale printing, to large sheet-fed presses for multicolour, high-volume commercial applications. In the interest of this research and the character of indigenous tanned leathers manual devices are used.

\section{MATERIALS AND METHODS}

The study mainly employed the experimental research, and it depended on studio activities which required the use of materials such as: indanthrene dyes (Vat dyes), cassava starch, water, sodium hydroxide (caustic soda), sodium hydrosulfite and indigenous vegetable tanned leather. The purposive sampling technique was used in selecting the materials for the study.
The activities of the experiments conducted were observed critically and recorded carefully. The results were documented cautiously.

Notwithstanding the fact that indanthrene dyes are commonly known for cellulose fibres than protein fibers as found with leather, the manipulation processes in the experiments critically revolved around the viscosity of the cassava starch as well as the reduction agents through application of varied quantities of sodium hydroxide and sodium hydrosulphite in different proportions. Three main experiments were conducted using varied quantities of auxochromes in the dye solutions and cassava starch in the paste preparation. The selected techniques for the application of paste were 'Screen Printing' and 'Dabbing'.

\section{Preliminary preparations for printing}

For the three experiments, three silk-screens with different motifs were developed for printing three separate colours of brown, light blue and black. The leathers were taken through secondary treatment of sanding the flesh side, soaking and stretching to secure them from dirt and offensive odour that often affect indigenous tanned leathers. To guarantee easy penetration of the dyes, the grain surface of the leathers were slightly buffed with emery paper to render them smooth and supple. Also to achieve softness and luster, burnishing was carried out. The leather surfaces were made slightly damp before executing the printing.

Experiment 1: Manipulating dye solution and preparation of cassava starch paste

As presented in Table 1, in the preparation of the indanthrene dyestuff solution for experiment 1 , the following quantities of reducing agents were used: $0.04 \mathrm{~g}$ of brown vat dye, $0.02 \mathrm{~g}$ of sodium hydroxide (caustic soda), and $0.08 \mathrm{~g}$ of sodium hydrosulfide were mixed with $150 \mathrm{ml}$ of hot water $\left(90^{\circ} \mathrm{C}\right)$ in a plastic container, the small quantity of water was meant to obtain a concentrated dye solution. The dye and the auxochromes were stirred to mix thoroughly and allowed to settle for maturity. In the 
Table 1: Variations of quantities of chemicals used in the three experiments

\begin{tabular}{llll}
\hline Chemicals & Experiment 1 & Experiment 2 & Experiment 3 \\
\hline Vat dye & $0.04 \mathrm{~g}$ (Brown colour) & $0.04 \mathrm{~g}$ (Light blue) & $0.04 \mathrm{~g}$ (Black) \\
Sodium hydroxide & $0.02 \mathrm{~g}$ & $0.01 \mathrm{~g}$ & $0.01 \mathrm{~g}$ \\
Sodium hydrosulfide & $0.08 \mathrm{~g}$ & $0.12 \mathrm{~g}$ & $0.16 \mathrm{~g}$ \\
Hot water $\left(90^{\circ} \mathrm{C}\right)$ & $150 \mathrm{ml}$ & $150 \mathrm{ml}$ & $150 \mathrm{ml}$ \\
Cassava starch flour & $0.2 \mathrm{~g}$ & $0.2 \mathrm{~g}$ & $0.2 \mathrm{~g}$ \\
Hot water $\left(90^{\circ} \mathrm{C}\right)$ & $600 \mathrm{ml}$ & $500 \mathrm{ml}$ & $500 \mathrm{ml}$ \\
\hline
\end{tabular}

(Source: Data from experiments conducted, 2012)

preparation of the cassava starch paste, a quantity of $0.2 \mathrm{~g}$ of cassava starch flour was mixed with $600 \mathrm{ml}$ of hot water $\left(90^{\circ} \mathrm{C}\right)$, and boiled to obtain a paste. It was poured into a 1 liter plastic container and the prepared dye solution was poured into the paste and stirred to mix thoroughly. The mixture was allowed to cool down for fifteen minutes before printing was executed. The leather was spread on the printing table and the paste was poured onto the reserve side of the screen after it was well positioned. With the aid of squeegee the paste was dragged over the screen to transfer the design onto the damp leather surface through the minute pores of the silk-screen as shown in Plate 1. Two sheets of leather were printed. With running water, the starch was washed off ten minutes after the printing, and the leathers were dried under a shade and made ready for use.

Experiment 2: Variation of dye auxochromes and cassava starch paste viscosity

In preparing the indanthrene dyestuff solution for experiment 2 , the following varied quantities of dye, reducing agents and water were used as shown in Table 1: $0.04 \mathrm{~g}$ of light blue vat dye, $0.01 \mathrm{~g}$ of caustic soda and $0.12 \mathrm{~g}$ of sodium hydrosulfide were mixed with $150 \mathrm{ml}$ of hot water $\left(90^{\circ} \mathrm{C}\right)$ in a plastic container. The

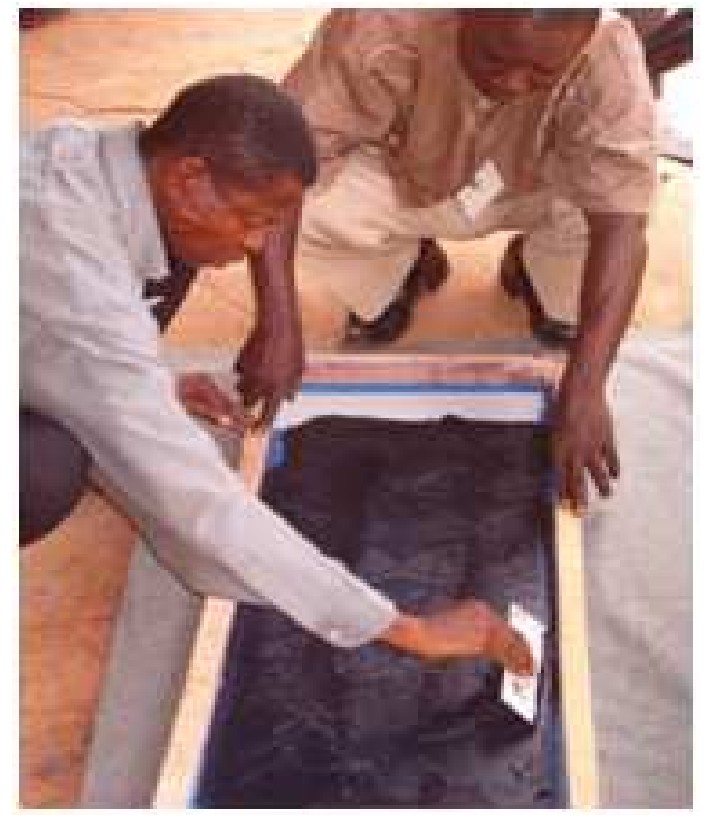

Plate 1: Screen printing on leather

small quantity of water was meant to obtain a concentrated dye solution. The dye and the auxochromes were stirred to mix thoroughly and left to settle for maturity. In the preparation of the cassava starch paste, a quantity of $0.2 \mathrm{~g}$ 
of cassava starch flour was mixed with $500 \mathrm{ml}$ of hot water $\left(90^{\circ} \mathrm{C}\right)$, and boiled to obtain a paste. It was poured into a one liter plastic container and the prepared dye solution was poured into the paste and stirred to mix thoroughly. The mixture was allowed to cool down for fifteen minutes, and printing was executed on two sheets of leather following the same printing, washing and drying processes described in experiment 1 .

Experiment 3: Further manipulation of auxochromes and viscosity of starch paste

In experiment 3 , the indanthrene dyestuff solution was prepared with the following quantities of chemicals (Table 1) ): $0.04 \mathrm{~g}$ of black vat dye, $0.01 \mathrm{~g}$ of caustic soda and $0.16 \mathrm{~g}$ of sodium hydrosulfide were mixed with $150 \mathrm{ml}$ of hot water $\left(90^{\circ} \mathrm{C}\right)$ in a plastic container. The small quantity of water was meant to obtain a concentrated dye solution. The dye and the auxochromes were stirred thoroughly to mix and allowed to mature. In the preparation of the cassava starch paste, a quantity of $0.2 \mathrm{~g}$ of cassava starch flour was mixed with $500 \mathrm{ml}$ of hot water $\left(90^{\circ} \mathrm{C}\right)$, and boiled to obtain a paste. It was poured into a one liter plastic container and the prepared dye solution was poured into the paste and stirred to mix thoroughly. As done in experiments 1 and 2, the mixture was allowed to cool down for fifteen minutes before printing was executed on two sheets of leather following the printing, washing and drying process described in experiment 1 .

\section{DISCUSSION OF RESULTS}

The three experiments conducted proved successful in terms of dye penetration with the auxochromes, printing process and wash fastness. The dyes penetrated the grain layer of the leather and bound with the fibers after washing off the cassava starch. This produced a deep printed hue and a smooth surface quality that is unfamiliar with other printing media when applied onto leather. The use of the starch as a vehicle allowed the concentration of dye solution in a given area confirming McLaughlin's (2001) observation that if leather is vat-dyed, the colour will be saturated through the leather's fibres and a colour change is virtually not impossible. Comparing the performance of the cassava starch paste in the three experiments, it was found that the outcome of experiment 1 was not up to expectation in terms of even spread and distribution since there was bleeding during printing. The cassava starch paste was found to be less viscous; thence the quantity of water used was reduced from $600 \mathrm{ml}$ to $500 \mathrm{ml}$ in experiment 2 and 3 in the starch paste preparation. This allowed smooth and easy spread control of the cassava paste using the squeegee (Cost, 2008).

It was also observed that the procedure followed in the dye preparation was in conformity with the approach by Baptista (2009). This guaranteed proper dissolution of the indanthrene dyes to mix well when reduced to the leuco form in an alkaline solution of sodium hydrosulfite and sodium hydroxide (caustic soda) before mixing with the cassava starch paste. The dye was able to penetrate the fibers of the leather because of the smooth soft grain surface created by buffing with emery paper as recommended in the "Printing Techniques and Preparations" by McLaughlin (2001). The prepared dye mixed perfectly with the starch resulting in a thick paste that was used as a vehicle for successful transfer of the vat dye onto the leather surface. It was realized however that the variations in the quantities of auxochromes used generally created differences in the appearance of the dye colours. In experiment 1 , the $0.02 \mathrm{~g}$ of sodium hydroxide used caused the brown dye to appear darker on the leather surface. When reduced to $0.01 \mathrm{~g}$ in experiments 2 and 3, light blue and black colours appeared well. It has also been observed that the increment of the sodium hydrosulfite in experiments 2 and 3 from $0.08 \mathrm{~g}$ in experiment 1 to $0.12 \mathrm{~g}$ to 0.16 continually increased the brightness of the dye colours.

Boahin, et al. (2011) have submitted that, vat dyes' colour intensity is achieved on leather only when there is adequate concentration and 


\section{Boahin et al.}

absorption of dye solution on the part of the leather being dyed. By allowing 10 minutes of time between printing and washing off the starch paste from the leather with running water, it was noticed that there was dye concentration and absorption, hence attainment of colour brightness after drying the leather. The research has also provided leather workers in Ghana with the opportunity of applying colouring agents in a variety of hues and a printing vehicle that can be secured easily on the market for printing on leather for enhanced aesthetics of leather products that can compete favourably on both the local and international markets. The illustrations in Plates 2 and 3 represent the outcome of experiments 2 and 3 which demonstrate the efficacy of cassava starch serving as a vehicle for printing dyes on leather.

The results of the study present another impetus of colour application on leather to enhance the aesthetics of locally made vegetable tanned leathers. The screen printing technique used provides indigenous leather workers with additional technique for colouring indigenous vegetable tanned leather. This has proven the possibility of printing indanthrene dyes on leather,

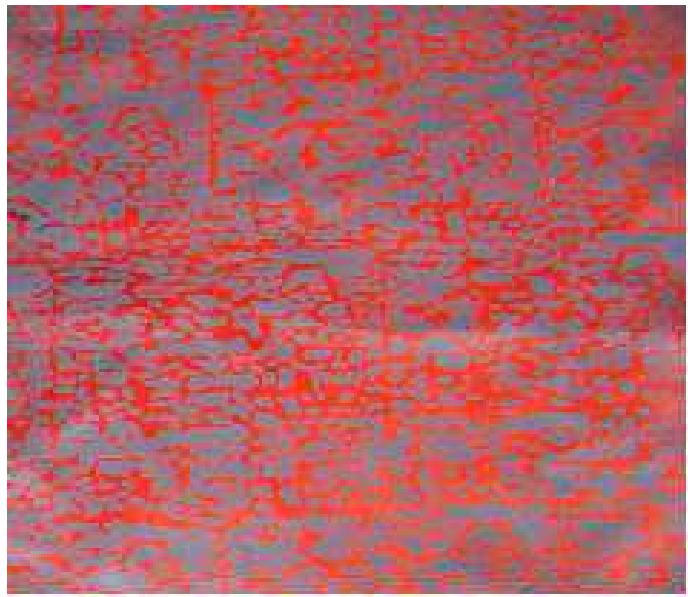

Plate 2: Printed motifs on red leather and has debunked the perception that the technique of vat dye applications has been considered to be the preserve of textile printers and fabric dyeing. Plates 4 and 5 illustrate finished leather artifacts made from the red and wine leathers screen printed with the indanthrene dyes.

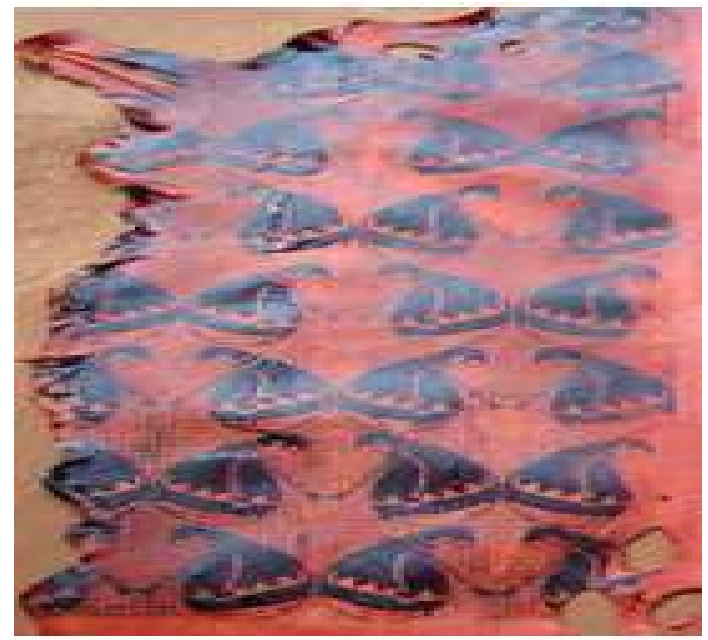

Plate 3: Printed motifs on wine leather

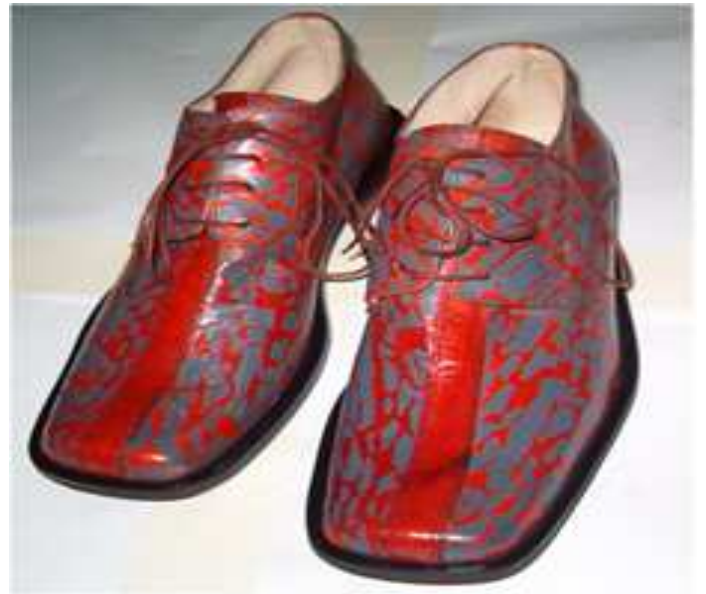

Plate 4: A pair of printed leather shoes 
Indanthrene-dye as colourant for screen printing on leather... 71

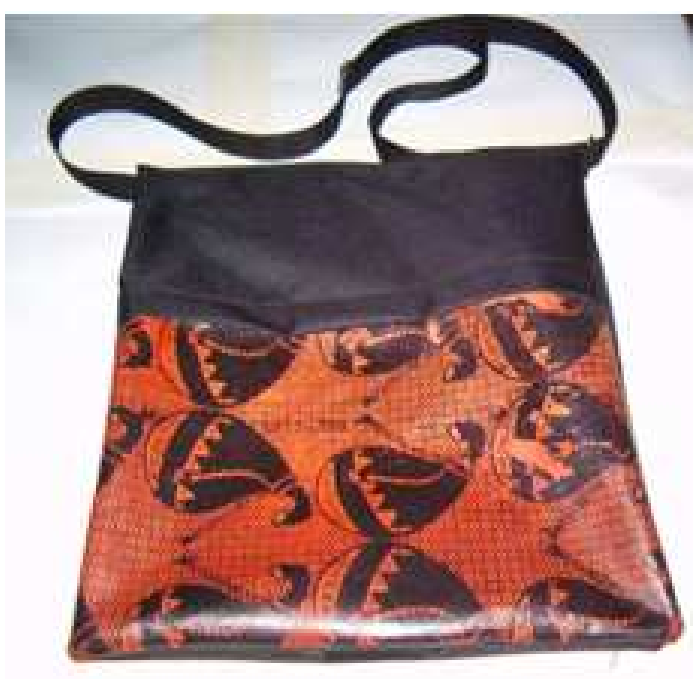

Plate 5: Printed ladies shoulder bag

\section{CONCLUSIONS}

The results of the research have asserted the possibility of manipulating indanthrene dye into a paste for printing on indigenous tanned leathers. Beside, the printing paste prepared from cassava starch has been found to be a useful vehicle for screen printing on appropriate viscosity and dye concentration. The temporary adherence of thick cassava paste of dye unto the surface of the leather ensured that the dyes could spread, leach, penetrate and fix to the fibers of the leather the guarantee wash fastness. The printing technique for colouring the leathers was found to be effective, and the fine molecular structure of the dye made penetration through the fibers of the leather easier since it occurred within 10 minutes after printing on the leather.

\section{RECOMMENDATION}

It is recommended that the manipulation process of the indanthrene dyes into paste for screen printing on indigenous tanned leathers be taught to leather tanners, leather artisans, leatherwork students and leather artifact processers to build capacity to improve the aesthetics of their products to enable them increase their competitiveness for accelerated patronage. Workshops, seminars and empowerment training for leatherworkers to adopt the identified printing technique are also recommended.

\section{REFERENCES}

Alen, R. L. M. (1971). Colour chemistry. Great Britain: Imperial Chemical Industries Ltd.

Asante, C. (1980). Textile for senior secondary schools and West African Colleges; Kumasi. New Era Ltd.

Baptista, J. R. (2009). "The Chemistry and Manufacture of Vat Dyes", Retrieved from http://www.colorantshistory.org/files/ Vat_Dye_Chemistry_Manufacture_Express_ PDF_version_web.pdf, on 1- 12-2011.

Boahin, J. O. B., Steiner, R. and Agyem, J. A., (2011). "Adapting vat dye as alternate dyeing agent for vegetable tanned leather" Journal of Science and Technology, 31, (2): 74-82

Boahin, J. O. B. (2008). Technical problems and solutions in the indigenous leather industry: Implications for Art Education in Ghana. KNUST, Kumasi: Unpublished Ph.D Dissertation, Dept. of General Art Studies.

Cost, F. (2008). "Printing Techniques." Microsoft ${ }^{\circledR}$ Student 2008 [DVD]. Redmond, WA: Microsoft Corporation, 2007.

Lewin, S. Z. (2008). "Dyestuffs." Microsoft ${ }^{\circledR}$ Student 2008 [DVD]. Redmond, WA: Microsoft Corporation, 2007.

McLaughlin, D. (2001). Printing techniques and preparations (edited 06-16-2001). USA: Powered by Bulletin Solutions Inc.

Nguyen, H. X. (2008). "Dyeing." Microsoft ${ }^{\circledR}$ Student 2008 [DVD]. Redmond, WA: Microsoft Corporation, 2007. 


\section{Boahin et al.}

Sackey S. K. (2000). Textiles for Schools and Colleges: Accra. Ask Publications.

Sharphouse, J. H. (1995). Leather Technician's
Handbook, LPA 75th Anniversary Edition. Northampton, UK: Leather Producers' Association. 